\title{
DO DIFFERENT TYPES OF FDI STRATEGIES SPUR PRODUCTIVITY AND INNOVATION CAPABILITY GROWTH? EVIDENCE FROM TAIWANESE MANUFACTURING FIRMS
}

\author{
Hui-Lin LIN ${ }^{1}$, Yi-Chi HSIAO ${ }^{2}$, Eric S. LIN ${ }^{3}$ \\ ${ }^{1}$ Department of Economics, National Taiwan University, \\ 21 Hsu-Chow Road, Taipei, Taiwan 10055 \\ ${ }^{2}$ Department of Strategy and Management. National Taiwan University, \\ 21 Hsu-Chow Road, Taipei, Taiwan 10055 \\ ${ }^{3}$ Department of Economics, National Tsing Hua University, 101, Sec.2, \\ Kuang-Fu Road, Hsin-Chu, Taiwan 30013 \\ Public Economics Research Center, National Taiwan University, \\ 21 Hsu-Chow Road, Taipei, Taiwan 10055

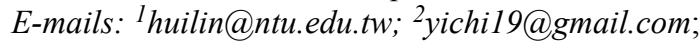 \\ 3slin@mx.nthu.edu.tw (corresponding author) \\ Received 05 January 2012; accepted 19 September 2012
}

\begin{abstract}
Based on different motivations for engaging in outward FDI, this study divides firms' outward FDI into five types: non-FDI, FDI, defensive only outward FDI, expansive only outward FDI, and both defensive \& expansive outward FDI simultaneously, and proposes four hypotheses to evaluate their relative strength in terms of firm productivity and innovation capability. The propensity score matching estimator based on a uniquely compiled Taiwanese manufacturing data set shows that, as firms engage in outward FDI, they have higher productivity growth rates compared to non-FDI firms. As for the further disengagement of the impacts of outward FDI, our empirical results indicate that expansive outward FDI tends to strengthen firms' productivity growth, while such a growthboosting effect is not statistically significant for defensive outward FDI. Moreover, as far as firms undertaking defensive \& expansive outward FDI simultaneously are concerned, we also find a positive and significant impact of outward FDI on productivity growth, but the effect is not as large as that for firms engaging solely in expansive outward FDI. This may imply that defensive outward FDI has some adverse effects on firms' productivity growth. As firm performance is measured by innovation growth, the average treatment effects are all significantly positive regardless of the type of outward FDI strategies. Nevertheless, engaging in defensive outward FDI is less advantageous to innovation growth than the expansionary outward FDI, as well as to defensive \& expansive outward FDI simultaneously.
\end{abstract}

Keywords: outward FDI, defensive outward FDI, expansive outward FDI, total factor productivity, average treatment effect, propensity score matching.

JEL Classification: F21, F23, O32. 


\section{Introduction}

The globalization of economic activities has aggravated the competition faced by manufacturers. In order to maintain competitiveness and increase productivity, outward foreign direct investment (FDI) has become an important globalization strategy for a manufacturer. According to the United Nations Conference on Trade and Development (UNCTAD 2010) World Investment Report 2010, from 1982 to 2009, the average annual growth rate of global foreign direct investment was above $10 \%$, and surpassed the amount of global output and exporting value. Taking the year 2009 as an example, the amount of outward FDI was around 1.1 trillion dollars, indicating that outward FDI has played an important role in the modern economy. As an emerging economy, Taiwan's outward FDI has experienced a noticeable expansion during the past twenty years ${ }^{1 .}$ The FDI outflows amounted to $\$ 1.8$ billion in 1991 , and this figure increased to $\$ 10.1$ billion in $2009^{2}$. This trend is reflected in a large body of literature accentuating the role of outward FDI in boosting the productivity of Taiwanese multinationals (e.g., Hsu, Liu 2002; Chen 2003; Liu, Huang 2005; Chang 2006; H. L. Lin, E. S. Lin 2010; Lin et al. 2011 just to name a few). It is worth noticing that the motivations underlying the engagement in overseas investment activities may vary across firms, and the gap needs to be filled up in the existing literature on the association between different types of outward FDI decisions and firm productivity and innovation capability, where the firm productivity and innovation are considered to be key factors for enhancing the competitiveness of firms in the context of globalization ${ }^{3}$.

In this study, we further divide outward FDI into two broad categories - defensive outward FDI and expansive outward FDI - based on the motives of foreign investment ${ }^{4}$. Our work complements the existing literature on the outward FDI $v s$. firm productivity and innovation nexus by classifying outward FDI into four types (i.e., the generic, defensive, expansive, and both defensive and expansive outward FDI). In particular, four hypotheses (to be detailed in Section 2) are proposed to empirically investigate the effects on firm productivity as well as the innovation capability, including that defensive outward FDI has a negligible impact on firm productivity, but is beneficial to promoting innovation growth.

\footnotetext{
${ }^{1}$ Note that the significance of outward FDI from emerging economies has been rising during the past three decades. Since the late 1980s, developing economies have been increasingly recognized as essential suppliers of global outward FDI. Their share of global outward FDI has increased from 3\% during the period $1978-1980$ to $12.3 \%$ over the period 2003-2005 (UNCTAD 2007).

2 The FDI statistics are obtained from the Industrial Development and Investment Center of the Ministry of Economic Affairs in Taiwan at the following link http://www.idic.gov.tw/html/c3409.htm

${ }^{3}$ We note that $\mathrm{Chen}$ and $\mathrm{Ku}$ (2000) consider the effect of two types of FDI strategies on sales growth and survival, and divide the firms into expansionary and defensive types based on outward FDI in high-wage or low-wage countries. Weng et al. (2010) also examine the firms' expansive and defensive outward FDI activities but focus on the impact on product quality.

${ }^{4}$ A related work by Lin et al. (2011) is focused on firms' production overseas and domestic strategies. Based on the production relations between parent firms and their foreign subsidiaries, Lin et al. (2011) divide the multinationals' production behavior into five strategies: vertical integration, foreign concentration, home concentration, horizontal integration, and heterogeneous horizontal integration.
} 
The verification of our hypotheses is implemented by compiling two data sources in Taiwan (the Taiwanese Industry, Commerce and Service Census, and the Survey on the Outward FDI of Taiwanese Manufacturers) to obtain a unique and comprehensive firm-level data set, which contains rich information on the characteristics of individual firms. Our empirical assessment starts by first adopting the methodology developed by Levinsohn and Petrin (2003) to calculate the total factor productivity (TFP) which is able to alleviate the potential simultaneity problem that usually accompanies the firm productivity estimation. Next, to analyze and compare the impacts of outward FDI strategies on the growth of productivity and innovation under different outward FDI strategies, we utilize the propensity score matching technique (e.g., see Rosenbaum, Rubin 1983) to estimate the causal effect, i.e., the average treatment effect on treated. Unlike previous studies that usually adopt the instrumental variables method, our propensity score matching approach deals with the causal relationship between the outward FDI decision and firm productivity/innovation variables.

Our empirical results support the proposed hypothesis that as firms engage in outward FDI, they have a higher productivity growth rate compared to firms without overseas investment (Barba Navaretti, Castellani 2004; Branstetter 2006; Hijzen et al. 2007; Neven, Siotis 1995; Pottelsberghe de la Potterie, Lichtenberg 2001). Furthermore, firms would experience the highest rate of productivity growth (and innovation growth) if they were to undertake expansive outward FDI only. On the contrary, firms merely engaging in defensive outward FDI reveal no benefit in terms of increasing productivity even though this type of outward FDI may still enhance innovation growth.

The rest of the paper is structured as follows. In the next section, we review the existing literature on the outward FDI vs. productivity/innovation relationship. The next section reviews the theoretical and empirical background of FDI vs. the firm productivity and innovation nexus. We then describes the hypotheses that we proceed to test in this article through linking theory and empirics to the two types of outward FDI strategies. The methodology section characterizes the data sources and variables, including the measurement of firm productivity and innovation growth. The estimation methodology and pretreatment variables are also discussed. Empirical resutls section provides the estimation results in this paper. The last section explores the theoretical and managerial implications of our empirical findings as well as the limitations and suggestions for future research.

\section{Theoretical and empirical background}

\subsection{FDI vs. firm productivity}

In the FDI literature, the impact of outward FDI on firms' productivity and innovation capability in the home country has been substantially discussed both theoretically and empirically ${ }^{5}$. In terms of the influence of engaging in outward FDI on firm produc-

\footnotetext{
${ }^{5}$ Previous studies also explore the effect of outward FDI on other firm prospects such as employment (Barba Navaretti, Castellani 2004; Lipsey et al. 2000; Blomström et al. 1997), survival (Chen, Ku 2000), exports (Svensson 1996), and so on.
} 
tivity (or productivity growth), in a neo-classical growth framework, outward FDI is positively associated with productivity growth since it increases the efficiency or the volume of investment to shift the production function with a high growth path. Outward FDI can also enhance firm productivity by increasing the number of product varieties or amount of capital equipment (Borensztein et al. 1998). The new technology, production processes, and management in regard to outward FDI are able to spill over to domestic firms and thus increase the productivity (Kinoshita 2001; Halpern, Muraközy 2005). While engaging in outward FDI may reduce production costs, multinationals may also face some disadvantages such as the costs of transferring technology to foreign affiliates which may reduce a firm's future productivity (Keller, Yeaple 2009). Lee et al. (2013) consider a vertical FDI-based model of heterogeneous firms and find that firms located in areas with more concentrated industrial agglomerations are more productive, while those engaging in outward FDI may not perform better in terms of total factor productivity.

The net benefits of outward FDI on productivity at the firm or industry level have been broadly identified in recent empirical studies. Bitzer and Görg (2009) indicate that the EU outward FDI in the EU manufacturing industries leads to a positive impact on the productivity of the manufacturing industry in most of the EU countries during the period 1973-2001. Jabbour (2010) uses French firm level data to find the positive effects of different types of offshoring (international sourcing and vertical FDI) on firm productivity. Görg et al. (2008) find that the offshoring of service production has a positive impact on the productivity of the Irish electronics industry but no significant effect in terms of the goods offshoring. Altomonte and Pennings (2009) find that changes in Romanian firms' total factor productivity are positively related to the first foreign investment in a specific industry and region in the period 1995-2001. Yang and Huang (2010) indicate that the outward FDI in low-wage countries may improve the productivity of Taiwanese manufacturing firms. However, several studies also suggest that the impact of outward FDI on firm productivity may not necessarily be significant, see, e.g., Liu and Tung (2005), Görg et al. (2008), and Lee et al. (2013) ${ }^{6}$. In particular, Lee et al. (2013) conclude that outward FDI in China has a positive but not significant impact on Taiwanese firm productivity when local industrial agglomerations and the endogeneity problem are taken into consideration. Liu and Tung (2005) provide evidence that vertical FDI to China has a negative contribution to both the level and growth of labor productivity using a sample of Taiwanese manufacturing firms.

\subsection{FDI vs. firm innovation}

Regarding the effect of outward FDI on domestic firm innovation, the theoretical predictions are mixed. Walz (1997), Petit and Sanna-Randaccio (2000) incorporate FDI and R\&D investment endogenously in a general equilibrium model and conclude that a positive association exists between outward FDI and R\&D investment when the technology levels in the receiving and investing countries are similar. By contrast, Thirlwall

\footnotetext{
${ }^{6}$ Imbriani et al. (2010) find that outward FDI tends to strengthen productivity in the manufacturing sector, but has a negative effect on productivity in the service sector.
} 
(1982) argues that outward FDI serves as a substitute for domestic investment and that the domestic R\&D investment will be reduced accordingly. Chen and Hsu (2003) reach the conclusion that the impact of outward FDI on a firm's domestic R\&D is not clear-cut on the basis of a three-stage game approach. Belderbos et al. (2006) predict that firms may reallocate more $R \& D$ investment to their foreign affiliates when the destination country has more technological opportunities and a large market, resulting in a decline in the parent firms' innovation activities.

Similar to the FDI $v s$. productivity nexus, the empirical studies on the effect of outward FDI on domestic innovation also give rise to mixed results. Lipsey (1994) first finds a positive relationship between outward FDI and innovation for American firms that move their low-technological production activities to low-cost countries. In considering the case of outward FDI to China, Yang et al. (2010) identify a positive relationship between outward FDI and innovation activities in terms of R\&D intensity and patents using an unbalanced panel data set of large enterprises for the period 1997-2005. The positive association between outward FDI and domestic innovation is also found in Lin and Yeh (2005) utilizing manufacturing firms in the Taiwanese electronics industry. Lecraw (1993) finds that Indonesian outward FDI firms improved their performance (including quality and management expertise) after moving production abroad. Nevertheless, Slaughter (2000) shows that outward FDI exerts no significant effect on domestic R\&D for the U.S.-headquartered multinationals. Fors (1997) indicates that the technology is transferred to foreign plants because the domestic R\&D has been employed in both home and overseas plants. Using the Japanese multinationals, Head and Ries (2002) find that the outward FDI may not positively affect the domestic skill intensity while the effect depends on the technology level of the FDI receiving country.

According to previous studies, increasing investment activities abroad might affect the firm's productivity and innovation through any of the following four channels. First, the relocation of production stages might increase productivity through a better allocation of resources. Secondly, firms that relocate their production overseas may cut back home production and scale down future investment, which may give rise to an adverse effect on the long-term competitiveness or R\&D activities. Thirdly, specialization might increase productivity through scale economies and/or learning. Lastly, outward FDI activities might expose the firm to new technologies, ideas and knowledge, and thus in turn promote domestic innovation activities. In the following section, we discuss how different types of outward FDI relate to firm productivity and innovation growth and propose several hypotheses for our empirical investigation.

\section{Hypotheses}

We have mentioned that the overseas production of firms can also be categorized into defensive and expansive types based on the motivation of multinational firms. In particular, four types of outward FDI activities are considered, that is, the generic (i.e., either conducting defensive or expansive outward FDI), defensive, expansive, and both defensive and expansive outward FDI. The generic type of outward FDI corresponds 
to the type that is widely discussed in the literature (see Section 1 for more detailed discussions). Most of the empirical results find a positive association between outward FDI and productivity/innovation, even though a negative effect may be concluded occasionally. It is most likely that, compared to non-FDI firms, those firms engaging in outward FDI activities are prone to increase their productivity and innovation capability. The following hypothesis can be formulated:

H1: There is a positive relationship between outward FDI and firm productivity/innovation.

When firms solely engage in expansive outward FDI activities, they seek to pursue business growth and expand their scale of production and sales by penetrating new markets abroad (see, e.g., Hymer 1960; Caves 1974; Buckley et al. 2007)7. In addition, firms engaging in expansive outward FDI may aim to enlarge the market and to exploit the specific advantage embodied in their intangible assets. In this case, foreign and domestic production are complements and might boost multinational firms' technology and productivity (Walz 1997; Li, Hu 2004; Huang, Lin 2009; H. L. Lin, E. S. Lin 2010). The benefit of cross-country knowledge spill-overs as firms engage in outward FDI can also be expected - suggesting that the expansive outward FDI strategy has a positive effect on firms' productivity/innovation growth since the opportunity to exploit and adopt the higher technology level is greater. Therefore, we propose the following hypothesis:

H2: There is a positive relationship between expansive outward FDI and firm productivity/innovation.

According to the global horizon theory, defensive outward FDI is a strategy used to maintain the business by seeking cheaper resources of production abroad when a firm loses its comparative advantage in the home market (see, e.g., Vernon 1966; Kojima 1973; Ozawa 1979). The different motivations for engaging in overseas production lead to the various impacts of the two types of outward FDI on the innovation or productivity of firms. As for the firms engaging in defensive outward FDI activity, the technology levels for products of firms are usually not high in the host country and other countries have the capacity to produce, and hence the competition is fierce. In order to survive in the harsh environment, firms have to substitute foreign production for domestic production to lower the cost of production. By moving production processes to the lowtechnological countries passively due to cost considerations (e.g., increased wages and land prices in the home country), they have little hope of surviving the tougher competition (Priit 2010). Then, this type of outward FDI might reduce the firms' domestic investment activities and may not have positive effects on firm productivity in the long run (Hsu, Liu 2002; Chen 2003; Hudson et al. 2005; Liu, Huang 2005; Chang 2006; Chiang 2008; Li, Roe 2008), even though reallocating production resources by cost reduction is beneficial to promoting the firm productivity. The net effect of defensive outward FDI on firm productivity is thereby uncertain. In spite of that, after defensive FDI firms survive the keen competition of the market, they are able to make some ef-

\footnotetext{
${ }^{7}$ Note that Buckley et al. (2007) argue that Chinese outward FDI hinges on foreign-market-seeking and resource-seeking motivations rather than the cost-reduction incentive.
} 
forts to innovate. Nevertheless, the innovating effect of this type of FDI production strategy is less than that induced by expansive outward FDI. It is thus interesting to test the hypothesis below:

H3: The relationship between defensive outward FDI and firm productivity is unclear, but there is a positive association between defensive outward FDI and innovation. In addition, the productivity and innovation growth induced by expansive outward FDI are greater than those of defensive outward FDI.

If a firm engages in both outward FDI strategies, what is the net effect on firm performance? From the above discussion we know that conducting the defensive outward FDI may not have a positive impact on improving firm productivity. The positive effect of conducting expansive outward FDI on productivity may be offset by the defensive outward FDI. Therefore, the productivity increasing effect of conducting both outward FDI strategies is not as strong as that merely involving expansive outward FDI. To the best of our knowledge, very few studies have made such a kind of comparison. The last hypothesis to be tested in this paper can be formulated as follows:

H4: The productivity growth boosting effect induced by merely engaging in expansive outward FDI is greater than that involving both defensive and expansive outward FDI.

\section{Methodology}

\subsection{Sample sources}

In the empirical application, we take advantage of the two data sources in Taiwan the Industry, Commerce and Service Census (ICSC) administered by the DirectorateGeneral of Budget, Accounting and Statistics (DGBAS) of Taiwan, and the Survey on the Outward FDI of Taiwanese Manufacturers (SOFTM) conducted by the Ministry of Economic Affairs (MOEA) in Taiwan, where the former includes detailed firm information such as revenue, total employment, capital utilization, and cost structure, while the latter provides data on the firms' overseas activities such as types of outward $\mathrm{FDI}^{8}$. By matching ICSC and SOFTM in 2001 and 2006, we are able to obtain rich information on the characteristics of individual firms and to compute the change in productivity and R\&D inputs between 2001 and 2006.

The 2006 SOFTM data set enables us not only to distinguish whether a firm is engaged in outward FDI activities or not, where we let $s_{1}$ denote outward FDI firms and $s_{o}$ represent non-FDI firms, but also to classify different types of outward FDI activities based on firms' motivations. The motivations regarding the overseas investment of each FDI firm were surveyed in the SOFTM questionnaire, where the question in the original questionnaire: "What are your motivations for overseas investment?" makes allowance for multiple answers with respect to fifteen possible choices. The Appendix details the fifteen questions and describes how we classify the choices into different types of

\footnotetext{
${ }^{8}$ Please refer to the supplementary Appendix (http://mx.nthu.edu.tw/ slin/JBEM_supp.pdf) for detailed descriptions of the two data sources.
} 
outward FDI production strategies. Based on the motivations answered by firms, we identify the following three types of outward FDI strategies - defensive only outward FDI $\left(s_{2}\right)$, expansive only outward FDI $\left(s_{3}\right)$, and defensive \& expansive outward FDI simultaneously $\left(s_{4}\right)$.

By combining the two data sets ICSC and SOFTM together, there are 5,599 firms in our sample, which contains the variables (i.e., number of employees, capital, electricity, etc.) required to estimate the firms' total factor productivity. To conduct the causal inferences, we first group the comparison pairs (e.g., FDI $s_{1} v s$. non-FDI $s_{o}$ ) and further delete observations with incomplete information and extreme values ( 0.05 and 99.5 percentiles), yielding the final sample of 3,568 firms (in the $s_{1} v s . s_{o}$ case) ${ }^{9}$. In addition to categorizing the above five types of outward FDI strategies $s_{0}$ to $s_{4}$, the following variables are constructed from our data set: 1) firm age (firm age), measured by the years of a firm staying in the market since its establishment; 2) degree of outsourcing (outsourcing expenditures), measured by the natural logarithm of a firm's outsourcing expenditures; 3) innovation ability (rd), measured by the natural logarithm of a firm's research and development expenditures; 4) efforts for sustainable development (environment expenditures), measured by the natural logarithm of a firm's environmental protection expenditures; 5) the dummy for whether to engage in triangular trade (triangular trade); and 6) eleven industrial dummy variables ${ }^{10}$. Note that the expenditures have been adjusted by the GDP deflator with 2006 being normalized to 100 and 2001 to 96.08. The description of variables is reported in Table 1.

Table 1. Variables description

\begin{tabular}{ll}
\hline \multicolumn{1}{c}{ Variables } & \multicolumn{1}{c}{ Description } \\
\hline firm age & the years of a firm staying in the market since it establishment \\
\hline $\begin{array}{l}\text { outsourcing } \\
\text { expenditures }\end{array}$ & $\begin{array}{l}\text { a firm's outsourcing expenditures, measuring the cost } \\
\text { for conducting outsourcing }\end{array}$ \\
\hline $\begin{array}{l}\text { rd expenditures } \\
\text { a firms' research and development expenditures, including } \\
\text { the patents and r\&d personnel expenditures }\end{array}$ \\
\hline $\begin{array}{l}\text { environment } \\
\text { expenditures }\end{array}$ & a firm's environmental protection expenditures \\
\hline triangular trade & whether a firm engages in triangular trade \\
\hline ind11 & Eleven industry dummies \\
\hline ind18 & Textile product \\
\hline ind19 & Chemical material \\
\hline
\end{tabular}

\footnotetext{
${ }^{9}$ For the exact number of observations in regard to the other three comparison pairs (e.g., pairs $s_{2}$ vs. $s_{o}, s_{3}$ vs. $s_{o}$, and $s_{32}$ vs. $s_{o}$ ), please refer to the summary statistics in Table 2 .

${ }^{10}$ The eleven 2-digit industries include the Textile product, Chemical material, Chemical product, Basic metal, Metal product, Electronic parts and components, Computer, communication, and audio and video electronic product, Electrical equipment, Machinery equipment, Transport equipment and repair, and other manufacturing industries.
} 
End of Table 1

\begin{tabular}{ll}
\hline \multicolumn{1}{c}{ Variables } & \multicolumn{1}{c}{ Description } \\
\hline ind24 & Basic metal \\
\hline ind25 & Metal product \\
\hline ind26 & Electronic parts and components \\
\hline ind27 & Computer, communication, and audio and video electronic product \\
\hline ind28 & Electrical equipment \\
\hline ind29 & Machinery and equipment \\
\hline ind30 & Transport equipment and repair \\
\hline ind33 & Other manufacturing industries \\
\hline
\end{tabular}

\subsection{Measures}

The main purpose of this paper is concerned with the impact of different types of outward FDI on firm productivity and innovation growth. The innovation capability can be constructed by computing the rate of growth of R\&D expenditures. We note that the rate of growth of R\&D expenditures may not well represent the innovation activities in accordance with the Community Innovation Survey developed by the European Commission, and the usual proxy variables such as patents, number of new products and innovation sales are not available in our data sets. According to the definition of firms' research and development expenditures in the Industry, Commerce and Service Census, the expenditures include innovation-related spending such as that on patents and R\&D personnel (while we cannot distinguish between patents and $R \& D$ equipment spending), and might serve the innovative capability in the current context.

It is usually an issue and it is difficult to accurately capture the real firm total factor productivity. We follow the methodology developed by Levinsohn and Petrin (2003) to obtain the firm productivity, which is designed to minimize the potential simultaneity problem in estimating firm level production functions by using intermediate inputs as instruments ${ }^{11}$, The procedure is detailed in the supplementary material.

\subsection{Estimation method}

Evaluating the causal effect of outward FDI on firm performance is not an easy task due to the fact that engaging in outward FDI is not a random assignment across firms. It is often the case that a firm self-selects the outward FDI activities and the conventional

\footnotetext{
${ }^{11}$ A key issue in the estimation of production functions is the correlation between unobservable productivity shocks and input levels. Therefore, ordinary least squares (OLS) estimates of production functions are biased and lead to inconsistent estimates of productivity. For an overview of the literature, please refer to Griliches and Mareisse (1998). Moreover, the Levinsohn and Petrin (2003) method that deals with simultaneity bias can be regarded as an extension of the popular Olley and Pakes (1996) method. Recent studies have applied the Levinsohn and Petrin (2003) method to compute the firm productivity, e.g., Parisi et al. (2006), Altomonte and Pennings (2009), Arbeláez and Torrado (2011).
} 
method then results in a biased estimate. In order to analyze the impact of different outward FDI strategies, including defensive and expansive outward FDI, on productivity and innovation growth, we use a propensity score matching technique (Rosenbaum, Rubin 1983; Caliendo, Kopeinig 2008), which can construct the counterfactual through the selection of a valid control group of firms that are as similar as possible in terms of observable characteristics to a treatment group of firms, and hence reduce the bias in the estimation of treatment effects with observational data sets ${ }^{12}$.

In this study, we have four treatments (i.e., $s_{1}, s_{2}, s_{3}$ and $s_{4}$ ) and hence have four outcomes to be compared with the outcome of the control group $\left(s_{o}\right)$. Before proceeding with the matching algorithms, one has to choose the pretreatment variables to identify a valid control group of firms that shares similar characteristics to firms in the treatment group ${ }^{13}$. We choose firm age (firm age), the degree of outsourcing (outsourcing expenditures), innovation ability (rd), efforts for sustainable development (environment expenditures), whether engaging in triangular trade (triangular trade) as well as eleven industrial dummy variables to serve as pre-treatment variables.

\section{Empirical results}

\subsection{Descriptive evidence}

Table 2 provides the summary statistics according to different pairs of outward FDI $v s$. non-FDI strategies ${ }^{14}$. Again, it is shown that engaging in outward FDI is highly associated with higher firm performance in terms of both productivity and innovation growth rates. The difference is that, compared to non-FDI firms, the expansive outward FDI firms on average have the highest firm productivity, while the defensive FDI firms accord with the highest R\&D growth rate. Table 2 also indicates that the firm age tends to be larger for FDI firms even though firms engaging only in expansive FDI do not last longer than non-FDI firms. It is not surprising to observe that firm's outsourcing expenditures are much lower for FDI firms since they are able to engage in overseas production activities directly through an outward FDI strategy. The environmental protection expenditures do not differ significantly for FDI and non-FDI firms. The fact that a higher proportion of FDI firms involves triangular trade is pretty much within our expectations.

In what follows, we will conduct an empirical investigation to analyze the impacts of outward FDI strategies on the growth of productivity and innovation, and then use the propensity score matching method to test the hypotheses proposed in Section 2.

\footnotetext{
${ }^{12}$ Stuart (2010) provides an excellent survey of causal inference and a step by step guide in order to conduct matching, including statistical software availability for some of the procedure.

${ }^{13}$ Please refer to the supplementary Appendix for implementing the matching methods.

${ }^{14}$ Without disentangling different types of outward FDI strategies, we also report the overall summary statistics in supplementary Appendix.
} 
Table 2. Summary statistics by different types of outward FDI Strategies

\begin{tabular}{lcccc}
\hline \multicolumn{2}{c}{$(\mathrm{A})$} & \multicolumn{2}{c}{$(\mathrm{B})$} \\
\hline & Non-FDI $\left(s_{o}\right)$ & FDI $\left(s_{1}\right)$ & Non-FDI $\left(s_{o}\right)$ & Def. FDI $\left(s_{2}\right)$ \\
\hline$\Delta \omega$ & $0.2367(1.257)$ & $0.4360(1.422)$ & $0.2610(1.358)$ & $0.2970(1.176)$ \\
\hline$\Delta v$ & $-0.7265(5.421)$ & $1.1974(4.249)$ & $-0.7327(5.425)$ & $1.3569(4.384)$ \\
\hline firm age & $16.3014(8.861)$ & $19.1521(10.877)$ & $16.2914(8.864)$ & $20.6849(9.498)$ \\
\hline $\begin{array}{l}\text { outsourcing } \\
\text { expenditures }\end{array}$ & $8.4331(7.671)$ & $5.7672(4.672)$ & $8.4522(7.677)$ & $5.7848(4.379)$ \\
\hline rd & $2.9895(6.083)$ & $6.1792(5.216)$ & $2.9775(6.086)$ & $4.8499(4.962)$ \\
\hline environment & $2.5263(5.135)$ & $2.5547(3.862)$ & $2.5183(5.132)$ & $2.6401(3.912)$ \\
expenditures & & & & \\
\hline triangular trade & $0.0959(0.295)$ & $0.3236(0.468)$ & $0.0964(0.295)$ & $0.3014(0.462)$ \\
\hline obs & 2,950 & 618 & 2,955 & 73 \\
\hline & & & & \\
\hline
\end{tabular}

Notes: 1) Data sources: 2001 and 2006 Taiwanese Industry, Commerce and Service Census, and Survey on the Outward FDI of Taiwanese Manufactures. 2) $\Delta \omega$ represents the rate of productivity growth, and $\Delta v$ represents the rate of innovation growth, which is measured by the rate of $R \& D$ growth. 3) Sample means of variables are reported and standard errors are in parentheses.

\subsection{Main results}

In the empirical application, we implement four sets of causal inferences: 1) non-FDI $v s$. outward FDI firms; 2) non-FDI vs. defensive only outward FDI firms; 3) non-FDI $v s$. expansive only outward FDI firms; and 4) non-FDI firms vs. firms undertaking both defensive \& expansive outward FDI. For each pair, the outcomes of interest are the rate of productivity growth $(\Delta \omega)$ and the innovation growth rate $(\Delta v)$; the treatment is the dummy for each type of outward FDI strategy $\left(s_{j \neq 0}\right)$. 
Table 3 provides the estimation results from the logistic regression, from which we can derive the propensity score, $P^{j}\left(s_{j}=1 / X_{i}\right)$, of each firm ${ }^{15}$. Note that the comparison benchmark is the non-FDI firms for each pair in the last four columns of Table 3. First of all, we can see that firm age has positive impacts on the probability of implementing outward strategies $s_{1}, s_{2}$ and $s_{4}$, but has no significant effect on the probability of performing $s_{3}$. Next, the results also indicate that outsourcing expenditures negatively affect the tendency of firms to engage in any type of outward FDI activities $\left(s_{1}, s_{2}, s_{3}\right.$ and $s_{4}$ ), while undertaking triangular trade to have a positive impact on the tendency to engage in outward FDI activities. The finding is consistent with the summary statistics presented in Table 2. As for the impacts of R\&D expenditures and environmental protection expenditures on the probability of making outward FDI strategic choices, we find that R\&D expenditures positively affect the probability of choosing outward FDI, expansive outward FDI and defensive \& expansive outward FDI simultaneously, while environmental protection expenditures negatively affect the propensity to engage in $s_{1}$, $s_{3}$ and $s_{4}$. This may be due to the fact that the Taiwanese government has imposed more stringent environmental protection laws in recent years and therefore firms choosing to stay home are likely to incur more costs in regard to environmental protection. However, further study is needed to confirm this argument.

Table 3. Estimation results from logistic regression

\begin{tabular}{lcccc}
\hline & FDI $\left(s_{1}\right)$ & Def. FDI $\left(s_{2}\right)$ & Exp. FDI $\left(s_{3}\right)$ & FDI Both $\left(s_{4}\right)$ \\
\hline firm age & $0.0356^{* * *}$ & $0.0509^{* * *}$ & 0.0130 & $0.0400^{* * *}$ \\
& $(0.0051)$ & $(0.0124)$ & $(0.0097)$ & $(0.0059)$ \\
\hline outsourcing & $-0.0573^{* * *}$ & $-0.0451^{* * *}$ & $-0.0565^{* * *}$ & $-0.0557^{* * *}$ \\
expenditures & $(0.0072)$ & $(0.0169)$ & $(0.0122)$ & $(0.0084)$ \\
\hline rd & $0.0466^{* * *}$ & 0.0107 & $0.0636^{* * *}$ & $0.0375^{* * *}$ \\
& $(0.0080)$ & $(0.0188)$ & $(0.0130)$ & $(0.0093)$ \\
\hline environment & $-0.0324 * * *$ & -0.0160 & $-0.0339^{*}$ & $-0.0331^{* * *}$ \\
expenditures & $(0.0108)$ & $(0.0246)$ & $(0.0186)$ & $(0.0127)$ \\
\hline triangular & $1.1133^{* * *}$ & $1.0473 * * *$ & $0.7444 * * *$ & 1.2451 \\
trade & $(0.1174)$ & $(0.2811)$ & $(0.2166)$ & $(0.1340)$ \\
\hline ind_dummies & yes & yes & yes & yes \\
\hline cons & $-1.1828^{* * *}$ & $-4.5392^{* * *}$ & $-2.4705^{* * *}$ & -1.7716 \\
& $(0.1350)$ & $(0.6054)$ & $(0.4435)$ & $(0.1622)$ \\
\hline chi2 & $535.75^{* * *}$ & $76.97 * * *$ & $176.13^{* * *}$ & 389.81 \\
\hline obs & 3,568 & 3,028 & 3,102 & 3,346 \\
\hline
\end{tabular}

Notes: 1) The base strategy is without outward FDI. 2) Standard errors are in parentheses. *, **, and $* * *$ denote statistical significance at the $10 \%, 5 \%$ and $1 \%$ levels, respectively.

${ }^{15}$ Based on the correlation matrix and variance inflation factor in supplementary Appendix, the collinearity problem should not be an issue in our analysis. 
After obtaining the propensity score for each firm based on the logistic regression, we proceed to estimate the average treatment effect on the treated ${ }^{16}$. We also adopt three matching algorithms (Nearest Neighbor matching, Radius matching and Kernel matching) to briefly check the robustness of our estimation results. The first column in Table 4 shows the ATT estimators (under three matching algorithms) as the treatment is "participation" in the outward FDI activity $\left(s_{1}=1\right)$ and the control group is the domestic counterfactual $\left(s_{o}=1\right)$. When we apply the innovation growth as our second firm outcome variable, which is measured by the R\&D growth, Table 5 reports the estimation results of ATT based on the rate of innovation growth $(\Delta v)$. It is found that the productivity and innovation growth rates of FDI firms are significantly higher than those of non-FDI firms (see the first columns in Table 4 and Table 5). The positive average causal effects on the productivity/innovation growth of overseas investment confirm Hypothesis 1 . More specifically, FDI firms have from $13.96 \%$ to $17.80 \%$, depending on different matching algorithms, higher productivity growth rates than their domestic counterfactual. The positive impact of outward FDI on productivity/innovation growth is consistent with most of the existing literature, e.g., Barba Navaretti and Castellani (2004), Branstetter (2006), Chen and Ku (2000), Hijzen et al. (2007), Neven and Siotis (1995), Pottelsberghe de la Potterie and Lichtenberg (2001), among many others.

To gain a more insightful understanding of the impacts of various outward FDI strategy combinations on firm productivity and innovation capability, the last three columns in Table 4 provide the ATT estimators in regard to the treatment indicators $s_{2}, s_{3}$ and $s_{4}$ versus the control counterpart $\left(s_{o}\right)$, respectively. It is observed that the ATT estimators under the treatment indicator $s_{3}$, in the range of 0.3111 and 0.3868 , are the largest among all treatments. Table 5 also shows that the ATT of innovation growth in regard to expansive outward FDI is the largest among all types of FDI activities. This finding indicates that firms engaging in expansive outward FDI $\left(s_{3}\right)$ have experienced higher productivity and innovation growth in comparison with the other three types of outward FDI firms $\left(s_{1}, s_{2}\right.$ and $\left.s_{4}\right)$. Our proposed Hypothesis 2 is therefore supported.

As for the firms that undertake defensive outward FDI $\left(s_{2}\right)$, the rate of productivity growth is not significantly better than that of the non-FDI firms - in some matching algorithms we even observe negative effects on productivity growth for firms engaging only in defensive outward FDI (see Table 4). This fact confirms Hypothesis 3 that firms engaging in defensive outward FDI reduce the firms' domestic investment activities and do not necessarily increase firm productivity. As discussed in Section 2, firms that conduct defensive outward FDI to survive the harsh environment have to innovate to

\footnotetext{
${ }^{16}$ We have performed the test of the balancing property for each treatment effect model based on Kernel matching method in supplementary Appendix. Radius and $k$-NN matching methods give rise to similar results which are available upon request from the authors. Roughly speaking, the balancing property states that for a given propensity score (i.e., $P^{j}\left(s_{j}=1 / X_{i}\right)$ ), the exposure to treatment (FDI strategy) is random and therefore treated and control firms should on average be observationally identical. The tables in supplementary Appendix show that the mean difference of the matched sample between the treated and control groups for each pretreatment variable (as well as the overall variables) does not deviate significantly.
} 
Table 4. Estimation of average treatment effect on the treated (outcome variable: rate of productivity growth)

\begin{tabular}{lcccc}
\hline Matching & FDI & Def. FDI only & Exp. FDI only & FDI Both \\
\hline Methods & $E\left[\Delta \omega^{1}-\Delta \omega^{o} \mid s_{1}=1\right]$ & $E\left[\Delta \omega^{2}-\Delta \omega^{o} \mid s_{2}=1\right]$ & $E\left[\Delta \omega^{3}-\Delta \omega^{o} \mid s_{3}=1\right]$ & $E\left[\Delta \omega^{4}-\Delta \omega^{o} \mid s_{4}=1\right]$ \\
\hline ATT by & $0.1396^{*}$ & -0.0363 & $0.3111^{*}$ & 0.1125 \\
\hline $\begin{array}{l}\text { NN } \\
\text { matching }\end{array}$ & $(0.0970)$ & $(0.2053)$ & $(0.2131)$ & $(0.1185)$ \\
\hline ATT by & $0.1780^{* * *}$ & -0.0297 & $0.3868^{* * *}$ & $0.1138^{*}$ \\
\hline $\begin{array}{l}\text { Radius } \\
\text { matching }\end{array}$ & $(0.0717)$ & $(0.1441)$ & $(0.1653)$ & $(0.0873)$ \\
\hline ATT by & $0.1741^{* * *}$ & 0.0261 & $0.3344^{* * *}$ & $0.1149^{*}$ \\
\hline $\begin{array}{l}\text { Kernel } \\
\text { matching }\end{array}$ & $(0.0677)$ & $(0.1401)$ & $(0.1409)$ & $(0.0779)$ \\
\hline Obs & 3,568 & 3,028 & 3,123 & 3,346 \\
\hline
\end{tabular}

Notes: 1) Comparison benchmark is non-FDI firms in each column. 2) Matching variables: firm age, outsourcing expenditures, rd, environment expenditures, triangular trade, industry dummies. 3) Standard errors are in parentheses. $*, * *$, and $* * *$ denote statistical significance at the $10 \%, 5 \%$ and $1 \%$ levels, respectively.

Table 5. Estimation of average treatment effect on the treated (outcome variable: rate of innovation growth)

\begin{tabular}{lcccc}
\hline \multicolumn{1}{c}{ Matching } & FDI & Def. FDI only & Exp. FDI only & FDI Both \\
\hline Methods & $E\left[\Delta v^{1}-\Delta v^{o} \mid s_{1}=1\right]$ & $E\left[\Delta v^{2}-\Delta v^{o} \mid s_{2}=1\right]$ & $E\left[\Delta v^{3}-\Delta v^{o} \mid s_{3}=1\right]$ & $E\left[\Delta v^{4}-\Delta v^{o} \mid s_{4}=1\right]$ \\
\hline ATT by & $5.0362 * * *$ & $3.3315^{* * *}$ & $5.5598^{* * *}$ & $4.4036^{* * *}$ \\
\hline $\begin{array}{l}\text { NN } \\
\text { matching }\end{array}$ & $(0.4230)$ & $(0.9565)$ & $(0.7361)$ & $(0.5244)$ \\
\hline ATT by & $3.9794 * * *$ & $2.6510^{* * *}$ & $4.7438^{* * *}$ & $3.8724 * * *$ \\
\hline $\begin{array}{l}\text { Radius } \\
\text { matching }\end{array}$ & $(0.2643)$ & $(0.6052)$ & $(0.4998)$ & $(0.3082)$ \\
\hline ATT by & $4.1645^{* * *}$ & $2.3482^{* * *}$ & $3.6675^{* * *}$ & $3.8250^{* * *}$ \\
\hline $\begin{array}{l}\text { Kernel } \\
\text { matching }\end{array}$ & $(0.2315)$ & $(0.5235)$ & $(0.3894)$ & $(0.2634)$ \\
\hline Obs & 3,568 & 3,028 & 3,123 & 3,346 \\
\hline
\end{tabular}

Notes: 1) Comparison benchmark is non-FDI firms in each column. 2) Matching variables: firm age, outsourcing expenditures, rd, environment expenditures, triangular trade, industry dummies. 3) Standard errors are in parentheses. $*, * *$, and $* * *$ denote statistical significance at the $10 \%, 5 \%$ and $1 \%$ levels, respectively. 
improve product quality (see Table 5). Hypothesis 3 also states that firms involved in expansive outward FDI lead to higher productivity/innovation growth than in defensive outward FDI, which is clearly verified by inspecting columns 2 and 3 in Tables 4 and 5. This result may suggest that the firms engaging in expansive outward FDI have more opportunities to improve their productivity through international knowledge spill-overs than the firms engaging in defensive outward FDI in respect of the motivations and destinations of FDI, and hence will enjoy higher productivity/innovation growth.

Since Hypothesis 3 implies that defensive outward FDI is not necessarily associated with enhancing firm productivity, it is quite interesting to examine whether the benefit of engaging in expansive outward FDI dominates when firms undertake both defensive $\&$ expansive outward FDI simultaneously $\left(s_{4}\right)$. Our results in Table 4 exhibit a positive and significant impact of this type of outward FDI $\left(s_{4}\right)$ on productivity growth - firms have a higher productivity growth rate ranging from $11.25 \%$ to $11.49 \%$ (according to different matching methods) than their non-FDI counterfactual. The effect on productivity growth, however, is not as strong as that based on solely undertaking expansive outward FDI. This result suggests that defensive outward FDI may reveal some adverse effects on firm productivity growth (e.g., Hsu, Liu 2002; Chen 2003; Hudson et al. 2005, Liu, Huang 2005; Chang 2006; Chiang 2008; Li, Roe 2008), and thus some benefits produced by expansive outward FDI are offset by such negative effects. Thereby, Hypothesis 4 is confirmed by this empirical finding. Moreover, Weng et al. (2010) argue that the strategy of expansive outward FDI is more effective than defensive outward FDI at improving product quality since domestic firms are able to learn more advanced technology from guest countries. The innovation boosting effect by expansive outward FDI will be stronger than the effect that defensive \& expansive outward FDI simultaneously $\left(s_{4}\right)$ provides. The last two columns in Table 5 generally support this fact ${ }^{17}$.

Lastly, it is noticeable that the ATT in regard to $s_{2}$ is the smallest among the three ATT estimators $\left(s_{2}, s_{3}\right.$ and $\left.s_{4}\right)$ in Table 5 , which is along the lines of our result in Table 4, implying that engaging in a defensive outward FDI is less advantageous to firm productivity/innovation than an expansionary type of outward FDI. In addition, such an innovation boosting effect by $s_{2}$ is not as strong as the effect that defensive \& expansive outward FDI simultaneously $\left(s_{3}\right)$ provides.

\section{Discussion}

The impact of (generic) outward FDI on firms' productivity and innovation capability in the home country has been substantially discussed both theoretically and empirically in the literature. In considering firms' FDI decisions on the basis of expansive and/or defensive motivations, this paper contributes to the literature by investigating the net effect on firm productivity/innovation if a firm engages in either or both of the outward FDI strategies. Four hypotheses are thereby proposed for our empirical investigation. The tests proceed by matching the two data sources in Taiwan, the Taiwanese Industry,

\footnotetext{
${ }^{17}$ We note that ATT estimators of expansive outward FDI based on $k$-NN and Radius matching methods are greater than the ATT of $s_{4}$, while the ATT estimators are very close in terms of Kernel matching.
} 
Commerce and Service Census (TICS) and the Survey on the Outward FDI of Taiwanese Manufacturers (SOFTM), to obtain a unique and rich firm-level data set. Both firm total factor productivity and innovation growth are considered to be the firm outcome variables. To accommodate the potential simultaneity problem, the method of Levinsohn and Petrin (2003) is applied to calculate the total factor productivity and the rate of productivity growth so-derived for each firm, while the innovation growth rate is measured by the growth rate of $(\log ) \mathrm{R} \& \mathrm{D}$ expenditures. We further take advantage of the SOFTM data to classify the outward FDI strategies into four types, namely, the typical outward FDI, defensive only outward FDI, expansive only outward FDI, and defensive $\&$ expansive outward FDI simultaneously. This enables us to obtain a more insightful understanding of the impacts of various outward FDI strategies on the rate of productivity and innovation growth. To overcome the endogeneity problem between firm performance and FDI engagement, we adopt the propensity score matching method to make a comparison of firm performance under different types of outward FDI strategies.

\subsection{Theoretical implications}

For a comparison of productivity growth between non-FDI and FDI firms, our matching estimator supports the results (Hypothesis 1) found in the existing literature where firms engaging in outward FDI have higher productivity and innovation growth rates compared to firms that do not engage in overseas investment activities (e.g., Barba Navaretti, Castellani 2004; Branstetter 2006; Chen, Ku 2000; Hijzen et al. 2007; Neven, Siotis 1995; Pottelsberghe de la Potterie, Lichtenberg 2001, among many others). The propensity score matching results also indicate that expansive outward FDI tends to strengthen firms' productivity and innovation growth, confirming Hypothesis 2. It implies that expansive outward FDI firms that seek to pursue business growth and expand the scale of production and sales by penetrating new markets abroad are prone to adjust the production strategy more efficiently and benefit more through cross-country knowledge spill-overs, thereby improving their productivity and innovation capability.

Nevertheless, it is found that such a growth-boosting effect is not statistically significant for defensive outward FDI. This result (Hypothesis 3) is consistent with many studies, such as Huang and Lin (2009), Li and Hu (2004), and Walz (1997). Even though the FDI production in general is beneficial to increasing firm productivity, the defensive outward FDI firms passively move the production process overseas in order to survive the harsh market and hence are unable to allocate their resources efficiently, reflecting the insignificant impact on firm productivity. After defensive FDI firms survive the keen competition of the market, they have some room to improve product quality by involving more innovative activities.

Moreover, as far as firms undertaking defensive \& expansive outward FDI simultaneously are concerned, we also find a positive and significant impact of outward FDI on productivity growth, but the effect is not as large as that based on engaging solely in expansive outward FDI, supporting Hypothesis 4. This may imply that defensive outward FDI has some adverse effects on firms' productivity growth (Hsu, Liu 2002; Chen 2003; Hudson et al. 2005; Liu, Huang 2005; Chang 2006; Chiang 2008; Li, Roe 2008), and such negative effects cancel out the benefits produced by expansive outward FDI. 


\subsection{Managerial implications}

Due to the globalization of the world economy, firms are actively looking for a variety of favorable investment opportunities to strengthen their technical standards, or to readjust their production plans to improve their production efficiency. Most of the existing literature indicates that outward FDI is positively associated with the domestic firm productivity and innovation of multinational firms, while few studies simultaneously look into the causal effect of defensive and expansive FDI strategies on firm productivity and innovation capability.

Our empirical finding signifies some managerial implications. If a firm intends to promote its productivity, this can be successfully achieved by conducting the (expansive) outward FDI actively based on expanding market share, searching for specific assets (such as R\&D capacity and output, design facilities and brand names), and adjusting the production of domestic plants and foreign subsidiaries dynamically. However, if a firm engages in the overseas production passively (defensive type of outward FDI) for surviving the keen market, this production policy will be invalid in enhancing firm productivity.

It is intuitive to observe that an expansive outward FDI will be helpful in increasing innovation activity since the policy stems from advancing high technology. We also find that the defensive outward FDI is also a valid production strategy to enhance firm innovation activities. It is because after survival in the harshly competitive market, continuing to increase product quality and conducting R\&D activities is the key to firms' long-run sustainability. As a final note, we emphasize that the most effective tool for experiencing higher productivity and innovation growth is to engage in an expansive outward FDI production strategy.

\subsection{Limitations and suggestions}

We have utilized the propensity score matching method to resolve the problem when assessing the causal effect between different types of outward FDI production strategies and firm productivity/innovation. Due to the data limitation, we do not include the FDI host countries as one of the pretreatment variables in this article, which have been identified as a factor that may affect firm productivity/innovation in previous studies, e.g., Yang and Huang (2010), Liu and Tung (2005). It would be worth collecting the host country information and conducting a further causal inference analysis for future studies.

Recently, Contessi and De Pace (2011) have disaggregated the FDI into several components (e.g., equity, debt, and reinvested earnings) and investigated the contraction of FDI in the United States during the recent financial crisis. It would be interesting to inspect the impacts of different components of FDI on firm productivity and innovation activities in our future research. We also leave with interested readers the future possibility of exploring the relationship between defensive/expansive outward FDI and firm performance (e.g., ROA, ROE and Tobin's $q$ ), which could make a contribution to the field. 


\section{Acknowledgements}

We would like to thank Joseph D. Alba, Charles Sawyer, the editor and anonymous referees for many useful comments and suggestions on earlier drafts of this paper. We would also like to acknowledge the very constructive comments from participants at the Western Economic Association International 87th Annual Conference in San Francisco, California. Eric S. Lin would like to express his great appreciation to the Public Economics Research Center, National Taiwan University for the extremely generous and thoughtful hospitality during his visit in the center. All remaining errors are our own.

\section{References}

Altomonte, C.; Pennings, E. 2009. Domestic plant productivity and incremental spillovers from foreign direct investment, Journal of International Business Studies 40: 1131-1148. http://dx.doi.org/10.1057/jibs.2008.99

Arbeláez, M. A.; Torrado, M. P. 2011. Innovation, R\&D investment and productivity in Colombian firms, IDB Working Paper Series, No. IDB-WP-251.

Barba Navaretti, G.; Castellani, D. 2004. Investments abroad and performance at home: evidence from Italian multinationals, CEPR Discussion Paper, No. 4284.

Belderbos, R.; Carree, M.; Lokshin, B. 2006. Complementarity in R\&D cooperation strategies, Review of Industrial Organization 28(4): 401-426. http://dx.doi.org/10.1007/s11151-006-9102-z

Bitzer, J.; Görg, H. 2009. Foreign direct investment, competition and industry performance, The World Economy 32(2): 221-233. http://dx.doi.org/10.1111/j.1467-9701.2008.01152.x

Blomström, M.; Fors, G.; Lipsey, R. E. 1997. Foreign direct investment and employment: home country experience in the United States and Sweden, Economic Journal 107(445): 1787-1797. http://dx.doi.org/10.1111/j.1468-0297.1997.tb00082.x

Borensztein, E.; Gregorio, J. D.; Lee, J. W. 1998. How does foreign direct investment affect economic growth?, Journal of International Economics 45(1): 115-135.

http://dx.doi.org/10.1016/S0022-1996(97)00033-0

Branstetter, L. 2006. Is foreign direct investment a channel to knowledge spillovers? Evidence from Japan's FDI in the United States, Journal of International Economics 68: 325-344.

http://dx.doi.org/10.1016/j.jinteco.2005.06.006

Buckley, P. J.; Clegg, L. J.; Cross, A. R.; Liu, X.; Voss, H.; Zheng, P. 2007. The Determinants of Chinese outward foreign direct investment, Journal of International Business Studies 38: 499-518. http://dx.doi.org/10.1057/palgrave.jibs.8400277

Caliendo, M.; Kopeinig, S. 2008. Some practical guidance for the implementation of propensity score matching, Journal of Economic Surveys 22(1): 31-72.

http://dx.doi.org/10.1111/j.1467-6419.2007.00527.x

Caves, R. E. 1974. Multinational firms, competition, and productivity in host country markets, Economica 41(162): 176-193. http://dx.doi.org/10.2307/2553765

Chang, S. C. 2006. The dynamic interactions among foreign direct investment, economic growth, exports and unemployment: evidence from Taiwan, Economic Change and Restructuring 38: 235-256. http://dx.doi.org/10.1007/s10644-006-9005-x

Chen, T. J. 2003. Will Taiwan be marginalized by China?, Asian Economic Papers 2(2): 78-97. http://dx.doi.org/10.1162/153535103772624817

Chen, C. L.; Hsu, F. S. 2003. Defensive foreign direct investment and endogenous R\&D, Academia Economic Papers 31(4): 577-603 (in Chinese). 
Chen, T. J.; Ku, Y. H. 2000. The effect of foreign direct investment on firm growth: the case of Taiwan's manufactures, Japan and the World Economy 12(2): 153-172.

http://dx.doi.org/10.1016/S0922-1425(99)00035-3

Chiang, H. H. 2008. The flying geese development model of the IT industry in East Asia, Journal of the Asia Pacific Economy 13(2): 227-242. http://dx.doi.org/10.1080/13547860801923616

Contessi, S.; De Pace, P. 2011. The (non-)resiliency of foreign direct investment in the United States during the 2007-2009 financial crisis, Federal Reserve Bank of St. Louis Working Paper, No. 2011-037B.

Fors, G. 1997. Utilization of R\&D results in the home and foreign plants of multinationals, Journal of Industrial Economics 45(3): 341-358. http://dx.doi.org/10.1111/1467-6451.00052

Görg, H.; Hanley, A.; Strobl, E. 2008. Productivity effects of international outsourcing: evidence from plant level data, Canadian Journal of Economics 41(2): 670-688.

http://dx.doi.org/10.1111/j.1540-5982.2008.00481.x

Griliches, Z.; Mareisse, J. 1998. Production functions: the search for identification, in Econometrics and Economic Theory in the Twentieth Century: The Ranger Prisch Centennial Symposium, Cambridge University Press, 169-203.

Halpern, L.; Muraközy, B. 2005. Does distance matter in spillover?, CEPR Discussion Paper, No. 4857.

Head, K.; Ries, J. 2002. Offshare production and skill upgrading by Japanese manufacturing firms, Journal of International Economics 58: 81-105.

http://dx.doi.org/10.1016/S0022-1996(01)00161-1

Hijzen, A.; Inui, T.; Todo, Y. 2007. The effects of multinational production on domestic performance: evidence from Japanese firms, RIETI Discussion Paper.

Hsu, C. M.; Liu, W. C. 2002. The role of Taiwanese foreign direct investment in China: economic integration or hollowing-out?, The Journal of the Korean Economy 5(2): 207-231.

Huang, S. C.; Lin, C. C. 2009. Is it a myth that outward foreign direct investment to China lowers Taiwan's competitiveness?, in The Tenth Annual Conference on Empirical Economics, 23 May, 2009, Chiayi, Taiwan.

Hudson, D.; Xia, T.; Yeboah, O. 2005. Foreign direct investment and domestic industries: market expansion or outsourcing?, Review of Agricultural Economics 27(3): 387-393.

http://dx.doi.org/10.1111/j.1467-9353.2005.00233.x

Hymer, S. H. 1960. The international operations of national firms: a study of direct foreign investment. PhD Thesis, MIT. Cambridge, MA: MIT Press.

Imbriani, C.; Pittiglio, R.; Reganati, F. 2010. Outward FDI and home-country performance: evidence from Italian manufacturing and service firms, in 6th International Scientific Conference, Business and Management 2010 Selected Papers, 1-14 May, 2010, Vilnius, Lithuaia.

Jabbour, L. 2010. Offshoring and firm performance: evidence from French manufacturing industry, World Economy 33(3): 507-524. http://dx.doi.org/10.1111/j.1467-9701.2010.01265.x

Keller, W.; Yeaple, S. 2009. Gravity in the weightless economy, NBER Working Paper, No. 15509 [online], [cited 5 January 2012]. Available from Internet: http://www.nber.org/papers/W15509.pdf Kinoshita, Y. 2001. R\&D and technology spillovers through FDI: innovative and absorptive capacity, CEPR Discussion Paper, No. 2775.

Kojima, K. 1973. A macroeconomic approach to foreign direct investment, Hitotsubashi Journal of Economics 14(1): 1-21.

Lecraw, D. J. 1993. Outward direct investment by Indonesian firms: motivation and effects, Journal of International Business Studies 24: 589-600.

http://dx.doi.org/10.1057/palgrave.jibs. 8490247 
Lee, Y.; Chyi, Y. L.; Lin, E. S.; Wu, S. Y. 2013. Do local industrial agglomeration and foreign direct investment to China enhance the productivity of Taiwanese firms?, The Journal of International Trade \& Economic Development 22(6): 839-865.

http://dx.doi.org/10.1080/09638199.2011.609601

Levinsohn, J.; Petrin, A. 2003. Estimating production functions using inputs to control for unobservables, Review of Economic Studies 70(2): 317-341.

http://dx.doi.org/10.1111/1467-937X.00246

Li, Y.; Hu, J. L. 2004. R\&D, FDI and efficiencies of small and medium-sized firms, in Proceedings of International Symposium on Foreign Trade, FDI, and Industrial Development, 1 January, 2004, Chiayi, Taiwan. Department of Economics, National Chung Cheng University, Chia-Yi, Taiwan.

Li, N. C.; Roe, T. L. 2008. Taiwanese outward investment: economic bane or boon?, Taiwan Economic Forecast and Policy 38(2): 73-109.

Lin, H. L.; Lin, E. S. 2010. FDI, trade and product innovation: theory and evidence, Southern Economic Journal 77(2): 434-464. http://dx.doi.org/10.4284/sej.2010.77.2.434

Lin, H. L.; Yeh, R. S. 2005. The interdependence between FDI and R\&D: an application of an endogenous switching model to Taiwan's electronics industry, Applied Economics 37: 1789-1799. http://dx.doi.org/10.1080/00036840500217093

Lin, H. L.; Hsiao, Y. C.; Lin, E. S. 2011. The choice of FDI production strategies for multinational firms: theory and evidence, Working paper. Department of Economics, National Tsing Hua University, Taiwan.

Lipsey, R. E. 1994. Outward direct investment and the US economy, NBER Working Paper, No. 4691.

Lipsey, R. E.; Ramstetter, E. D.; Blomstrom, M. 2000. Outward FDI and parent exports and employment: Japan, the United States, and Sweden, NBER Working Paper, No. 7623.

Liu, B. J.; Huang, F. M. 2005. Outward direct investment, reverse import, and domestic production: evidence from Taiwanese manufacturing firms, Hitotsubashi Journal of Economics 46(1): $65-84$.

Liu, B. J.; Tung, A. C. 2005. Export outsourcing and foreign direct investment: evidence from Taiwanese exporting firms, in Dynamics, Economic Growth, and International Trade Conference, 10 June, 2005, University of Iceland, Iceland.

Neven, D.; Siotis, G. 1995. Technology sourcing and FDI in the EC: an empirical evaluation, International Journal of Industrial Organization 14(5): 543-560.

http://dx.doi.org/10.1016/0167-7187(95)00510-2

Olley, S.; Pakes, A. 1996. The dynamics of productivity in the telecommunications equipment industry, Econometrica 64: 1263-98. http://dx.doi.org/10.2307/2171831

Ozawa, T. 1979. International investment and industrial structure: new theoretical implications from the Japanese experience, Oxford Economic Papers 31(1): 72-92.

Parisi, M. L.; Schiantarelli, F.; Sembenelli, A. 2006. Productivity, innovation and R\&D: micro evidence for Italy, European Economic Review 50: 2037-2061.

http://dx.doi.org/10.1016/j.euroecorev.2005.08.002

Petit, M.; Sanna-Randaccio, F. 2000. Endogenous R\&D and foreign direct investment in international oligopolies, International Journal of Industrial Organization 18(2): 339-367.

http://dx.doi.org/10.1016/S0167-7187(98)00028-9

Pottelsberghe de la Potterie, B.; Lichtenberg, F. 2001. Does foreign direct investment transfer technology across borders?, Review of Economics and Statistics 83(3): 490-497.

http://dx.doi.org/10.1162/00346530152480135 
Priit, V. 2010. Does FDI spur innovation, productivity and knowledge sourcing by incumbent firms? evidence from manufacturing industry in Estonia, William Davidson Institute Working Papers Series wp986. William Davidson Institute at the University of Michigan.

Rosenbaum, P.; Rubin, D. 1983. The central role of the propensity score in observational studies for causal effects, Biometrika 70(1): 41-55. http://dx.doi.org/10.1093/biomet/70.1.41

Slaughter, M. J. 2000. Production transfer within multinational enterprises and American wages, Journal of International Economics 50(2): 449-472.

http://dx.doi.org/10.1016/S0022-1996(98)00081-6

Stuart, E. A. 2010. Matching methods for causal inference: a review and a look forward, Statistical Science 25(1): 1-21. http://dx.doi.org/10.1214/09-STS313

Svensson, R. 1996. Effects of overseas production on home country exports: evidence based on Swedish multinationals, Weltwirtschaftiches Archiv 132: 304-329.

http://dx.doi.org/10.1007/BF02707809

Thirlwall, H. R. 1982. De-industrialization in the UK, Lloyds Bank Review 134: 22-37.

UNCTAD. 2007. World investment report: transnational corporations, extractive industries and development. United Nations Conference on Trade and Development

UNCTAD. 2010. World investment report: investing in a low-carbon economy. United Nations Conference on Trade and Development.

Vernon, R. 1966. International investment and international trade in the product cycle, Quarterly Journal of Economics 80(2): 190-207. http://dx.doi.org/10.2307/1880689

Walz, U. 1997. Innovation, foreign direct investment and growth, Economica 64: 63-79. http://dx.doi.org/10.1111/1468-0335.00064

Weng, Y. H.; Yang, C. H.; Tu, F. C. 2010. Outward foreign direct investment and product quality of domestic productions: an empirical investigation, Journal of Business Economics and Management 11(3): 396-414. http://dx.doi.org/10.3846/jbem.2010.19

Yang, C. H.; Huang, C. H. 2010. FDI modes and parent firms' productivity in emerging economies: evidence from Taiwan, Working paper. Department of Economics, National Central University, Taiwan.

Yang, C. H.; Lin, H.; Wu, I. Y. 2010. Outward investment to China and domestic innovation of Taiwanese manufacturing firms, Japanese Economic Review 61(4): 538-557.

http://dx.doi.org/10.1111/j.1468-5876.2009.00498.x

\section{APPENDIX}

\section{Motivations for engaging in FDI}

The survey questionnaire in SOFTM contains fifteen questions in regard to the motivations for engaging in outward FDI activities. The fifteen motivations comprise:

1) for the potential development of the overseas market;

2) meet the needs of overseas customers;

3) follow up clients for potential markets;

4) support or encouragement from foreign governments;

5) access to advanced technology;

6) easy access to land resources;

7) easy access to cheap raw materials;

8) tax exemption and Most-Favored-Nation treatment from the foreign government; 
9) efficient usage of capital and technology;

10) declining revenue rate in host company;

11) enforced strategic alliances with overseas enterprises;

12) to promote brand awareness;

13) easy access to cheap labor;

14) to enhance export competitiveness; and

15) other incentives.

These motivations are further categorized into two broad groups: a) market $\&$ technology motivation: firms choosing motivations 1), 2), 3), 5), 9), 11), 12) and 14), and b) factor motivation: firms choosing motivations 4), 6), 7), 8), 10) and 13).

That is, for multinational firms, if their motivations underlying their overseas investment are only focused on seeking cheaper production resources abroad, including being able to access an abundant labor force, land or raw material resources (i.e., choosing at least one answer among motivations 4), 6), 7), 8), 10) and 13)), we refer to this type of investment as defensive only outward FDI $\left(s_{2}\right)$; if the motivations are only related to pursuing business growth and expanding the scale of production and sales by penetrating new markets abroad (i.e., choosing at least one answer among motivations 1), 2), $3), 5), 9), 11), 12$ ) and 14)), then we classify it as (only) expansive outward FDI $\left(s_{3}\right)$; if motivations simultaneously include factor and marketing incentives (i.e., choosing at least one answer in both two groups of motivations), then we define the strategy as strategy $s_{4}$. Note that in our classification firms either engaging in defensive or expansive outward FDI are regarded as belonging to $s_{1}$.

Hui-Lin LIN is a Professor at the Department of Economics and the Dean of Social Sciences, National Taiwan University. She earned PhD from Brown University at USA in May 1991. She has been a Professor of economics for 20 years. Her research focuses on econometrics, industrial economics and economic innovation. She has published many articles in international journal and 5 books in Taiwan.

Yi-Chi HSIAO, B.A. in Economics (National Central University, 2002); M.A. in Economics (National Taiwan University, 2004; University of Texas at Austin, 2008); Now is a PhD student in the Department of Strategy and Management at National Taiwan University. Research interests include applied econometrics and industrial organization.

Eric S. LIN, B.A. in Economics (National Taiwan University, 1993); M.A. in Economics (National Taiwan University, 1995); PhD in Economics (University of Texas at Austin, 2004); Professor, Department of Economics, National Tsing Hua University (2013). His research and publications are in the areas of economic forecasting, industrial economics, labor economics, and defence economics. 